\title{
VADEMECUM PRO DIALOG A HLÁSÁNÍ KRISTA MUSLIMU゚M V ČESKÉ REPUBLICE*
}

L U K Á Š NOSEK

\section{ABSTRACT \\ Vademecum for dialogue and proclamation of Christ to Muslims in the Czech Republic}

The article presents a practical guidance for catechists, preachers and pastoral workers and for their possible contact with Muslims in the Czech republic. This article presents a strong and joyful faith in the Christ in one hand and a desire of understanding between religions as a needed preconditions for the Interreligious Dialogue. The preacher has to be acquainted with the deep knowledge of Islam, its culture and the local muslim community. Also his rhetorical skills and a strong personality are strongly required. Further it shows the inspiration of proclamation of Christ which is based on similarities of the Bible and the Koran, and of the articles of faith and of the piety. At the end it is highly important to mention the knowledge of the classical Arabic literature and to search for elements of truth in it.

\section{Keywords}

Dialogue; Proclamation; Preacher; Islam

DOI: $10.14712 / 23363398.2018 .16$

\section{Současný svět charakterizovaný globalizací, migrací, míse-} ním kultur i projevů náboženství již nevede přemýšlivého jedince k otázce po tom, zda vykonávat mezináboženský dialog, či nikoliv.

* Text vychází ze dvou setkání s českou dominikánskou rodinou: 1) beseda na téma „Hlásáni krestanství jiným náboženstvím, zejména muslimům", která se konala v Praze dne 15. ř́jna 2016; 2) přednáškový cyklus pro stálé studium České dominikánské provincie na téma „Islám v ČR - výzva pro pastoraci“, který se konal v Olomouci dne 29. dubna 2017. Autor se snažil v textu zohlednit připomínky a společné myšlenky z obou setkání. 
Tato otázka je již zodpovězena. A to nejen v myslích hloubavých jedinců, ale i v lůně katolické církve. Dávno je již překonán názor - který se však stále ozývá -, že totiž mezináboženský dialog hraničí s blasfémií, že jde o odmítání Kristova evangelia, že jde o relativizaci jedinečné křestanské spásy, či dokonce že se s nepřáteli zásadně nevyjednává.

Papež František aktualizuje církevní pohled na vztah ke světu prizmatem nezbytného dialogu, tak jak to učil Druhý vatikánský koncil či papež Pavel VI. ve své encyklice Ecclesiam Suam. ${ }^{1}$ Dialog, jehož pravzor je v Nejsvětější Trojici a promítá se ve vztahu církve k celému světu, se musí aktualizovat i na poli mezináboženského dialogu. Přečtěme si slova papeže Františka z jeho apoštolské exhortace Evangelii gaudium, kde píše: „Postoj otevřenosti v pravdě a lásce musí charakterizovat dialog s věřícími nekřestanských náboženství, navzdory různým překážkám a obtížím, zejména fundamentalismům na obou stranách. Tento mezináboženský dialog je nezbytnou podmínkou míru ve světě, a proto je povinností pro křestany, jakož i pro ostatní náboženská seskupení. Zmíněný dialog je $\mathrm{v}$ první řadě místem rozhovoru o lidském životě, nebo jednoduše, jak navrhují indičtí biskupové, postojem otevřenosti vůči nekřestanům tak, že sdílíme jejich radosti a jejich bolesti.“2 Papež tedy uvažuje o dialogu mezi náboženstvími dokonce jako o povinnosti křestana.

Abychom mohli dostát těmto papežovým slovům, rádi bychom nyní čtenáři nabídli několik myšlenek a tipů, které by mu mohly pomoci v přístupu k muslimům. Nejprve předložíme obecné myšlenky ohledně dialogu (1.), které nás upozorní, že neexistuje dialog bez hlásání radostné zvěsti. Později představíme myšlenky o předpokladech k dialogu (2.). Dále se chceme konkrétněji zamyslet nad charakteristikami muslimských posluchačů a předložit několik námětů, „jak“ hlásat evangelium (3.) a čím si pomoci při jeho hlásání (4.).

1 Srov. Pavel VI. Ecclesiam Suam (encyklika ze dne 6. srpna 1964). Acta Apostolicae Sedis 56 (1964), s. 651-653.

2 František. Evangelii gaudium (apoštolská exhortace o hlásání evangelia v současném světě, ze dne 24. listopadu 2013). Praha: Paulínky 2014, s. 150 (čl. 250). 


\section{Dialog jako součást křestanské identity ${ }^{3}$}

Nejprve bychom chtěli jednoznačně zdůraznit, že mezináboženský dialog a hlásání Kristova evangelia jsou dvě aktivity církve, které jsou neoddělitelně spojeny, i když od sebe rozlišeny. Dialog neexistuje bez hlásání Krista, tak jako neexistuje hlásání Krista bez dialogu. Jsou to sice do jisté míry svébytné disciplíny, ale rozhodně nejsou odlišné.

Dialog samotný je přímo vepsán do církevní DNA. Církev je esenciálně dialogická. Společenství třech božských osob je prazáklad dialogu. Dialog jako vyjití ze sebe k druhému, jako bezmezné odevzdání sebe druhému. Ovšemže termín dialog je pak lidským pokusem popsat vnitrotrinitární vztahovost, která existuje primárně mezi Otcem a jeho Synem, tak jako mezi Synem a jeho Otcem. A onen vztah sebevydanosti je láskou, kterou není nikdo jiný než sám Duch lásky, Duch vzájemného obdarování, Duch svatý. A právě on by měl být hlavním aktérem dialogu a hlásání Krista.

Platí také, že dialog vychází z hlásání a vede k hlásání. Nejde rozhodně pouze o nějaký typ skryté křestanské propagandy. Jde o mnohem hlubší skutečnost. Již tím, že vstupuji do dialogu s nevěřícím nebo věřícím jiného náboženství, odkazuji na svou víru a svědčím o ní. Očima víry uznávám svého druha za člověka Bohem stvořeného podle Božího obrazu, tedy uznávám ho za sobě rovného. Také pokorně uznávám, že nejsem vlastníkem pravdy, ale jejím služebníkem, vždyt' Pravda nás nekonečně přesahuje a sama se nám dává. ${ }^{4}$ Jestliže jsem

3 Srov. Segretario per i non Cristiani. L'Atteggiamento della chiesa di fronte ai seguaci di altre religioni (Riflessioni e orientamenti su dialogo e missione, Roma, 10 maggio 1984). In: Francesco Gioia (ed.). Pontificio Consiglio per il Dialogo Interreligioso, Il Dialogo Interreligioso nell'Insegnamento ufficiale della Chiesa Cattolica (1963-2013). Città del Vaticano: LEV 2013포 s. 1802-1818; Pontificio Consiglio per il Dialogo Interreligioso. Dialogo e Annuncio (Riflessioni e orientamenti sul dialogo interreligioso e sull'Annuncio del Vangelo di Gesù Cristo, Roma, 19 maggio 1991). In: Francesco Gioia (ed.). Pontificio Consiglio per il Dialogo Interreligioso, s. 1856-1901; Pontificio Consiglio per il Dialogo Interreligioso. Testimonianza cristiana in un mondo multi-religioso (Raccomandazioni per il comportamento, Bangkok, 28 Gennaio 2011). In http://www.vatican.va/roman_curia/pontifical_councils/interelg/documents/rc_pc _interelg_doc_20111110_testimonianza-cristiana_it.html [4.11.2017]; Pontificio Consiglio per il Dialogo Interreligioso. Dialogo nella Verità e nella Carità. Orientamenti pastorali per il Dialogo Interreligioso (Roma 19 maggio 2014). Città del Vaticano: LEV 2014 (také: http://www.shinmeizan.com/images/PDF/DialVerCar.it.pdf).

4 Srov. Jean-Jacques Pérennès. Vescovo tra i musulmani. Pierre Claverie martire in Algeria. Roma: Città Nuova 2004, s. 393; Catherina Cornille. Conditions for the Possibility of Interreligious Dialogue. In: Christiane Timmerman - Barbara Segaert (eds.). How to Conquer the Barriers to Intercultural Dialogue. Christianity, Islam and Judaism. 
křestanem, pak dialog je nutnou součástí mé identity a mého pohledu na druhého, přesně tak, jak to činil Ježíš. I přesto, že ve chvíli falešného obvinění ztichl a nechal se přibít na kříž. Není toto Ježíšovo ticho neodlučitelný moment dialogu? Ježíšovo poslušné, pokorné sebevydání, aby tím svědčil pravdě a lásce, která je silnější než lež a smrt.

Je také evidentní, že neexistuje jiný způsob, jak hlásat Krista, než dialogicky. Není právě dialog jedinou možnou formou předání radostné zvěsti? Víra je přece ze slyšení (viz Řím 10,17)! Někdo hovoří a druhý poslouchá. Hlasatel poslouchá životní názor a snaží se porozumět situaci posluchače a následně reaguje svým hlásáním. Posluchač se dále ptá na nejasné části hlásání a hlasatel mu odpovídá. Takovýto dialog je právem konstitutivní metodou hlásání.

\section{Předpoklady dialogu a hlásání evangelia muslimům v Č́n}

To, co jsme právě nastínili, je však nutné doplnit o důležitý aspekt. Je totiž zapotřebí, aby hlasatel Kristovy zvěsti a ten, který vstupuje do dialogu s představiteli jiných náboženství, byli náležitě připraveni a formováni. Tato př́prava a formace se dá popsat nutnými předpoklady k dialogu. Pojd'me si jich pár představit.

a) Když opět budeme citovat slova papeže Františka z jeho apoštolské exhortace Evangelii gaudium, všimneme si hned prvního nutného předpokladu, který papež zmiňuje právě v souvislosti s islámem. „Pro dialog s islámem je neodmyslitelná náležitá formace zúčastněných stran nejenom proto, aby byli pevně a radostně zakořeněni ve své identitě, ale proto, aby byli schopni uznat hodnoty druhých, porozumět starostem, které stojí za jejich požadavky, a zdůrazňovat společná přesvědčení“6 Tato slova v prvé řadě naznačují, že dialog je postaven na pevném a radostném zakořenění ve vlastní identitě. To je nakonec jasný a přesvědčivý důkaz předložený všem kritikům dialogu. Nejedná se o proselytismus, synkretismus, relativizování či opuštění vlastních pozic. Právě naopak! Pravdivý a upřímný dialog předpokládá vlastní pevnou a především radostnou víru. Kdo není zakořeněn ve víře a ode

Brussels: P.I.E. - Peter Lang s. a., 2005, s. 25-42; Emilio Platti. Interreligious Dialogue from a Christian Perspective. In: Timmerman - Segaert. How to Conquer the Barriers to Intercultural Dialogue, s. 43-47.

5 Srov. Samir Khalil Samir. Papež František a pozvání k dialogu s islámem. Communio MKR 78 (2016), č. 1, s. 93-104.

${ }_{6} \quad$ František. Evangelii gaudium, s. 152 (čl. 253). 
všech duchovních odnoží si bere, co se mu zlíbí a co mu vyhovuje, nebude kvalitním partnerem mezináboženského dialogu. To, že jsem zakořeněn ve víře a pevně přesvědčen o tom, že Ježíš Kristus, náš Pán, je Spasitel a Spasitel všech, mi dává onen pevný a radostný základ k přesvědčivému svědectví, že nás pravda osvobodí.

b) Jak jsme již výše řekli, garantem a hlavním aktérem dialogu je Duch svatý. Proto jako jeden z hlavních předpokladů k dialogu by měla být modlitba a v ní tiché usebrání se vedoucí k pokorné vydanosti pravdě, jejímž přesvědčivým svědkem chci být, a důvěřivé spolehnutí se, že jenom Duch povede druhého k pravdě.

c) Na obou stranách dialogu by měla být hlavním motivem chut́ porozumět druhému. Jak jsme již zmínili, jestliže druhého před sebou považuji za partnera hodného dialogu, pak to vychází ze společného lidství, do kterého jsme byli oba povoláni Stvořitelem, byli jsme stvořeni podle obrazu Božího a jsme zacíleni k dobru (srov. Gaudium et spes).

d) Jestliže nás Pravda přesahuje, pak to také může znamenat, že i jinověrec mne může obohatit, protože ve své tradici uchovává prvky pravdy, semena Pravdy, semena Slova (Lumen gentium, čl. 16, Nostra aetate). Dialog tedy patří k mé víře, vždyt' se týká kultivace víry. Tak může být nejenom účinnou zbraní proti sebestřednosti a pýše, ale může jít o předání pravdivých semen Slova.

e) K nutným předpokladům dialogu patří jistě také upřímná a aktivní snaha uzdravit lidský rod. Nelze nevidět, že ve všech náboženských systémech jsou jedinci a skupiny, kteří myslí pro-humánně. Většina světových náboženství světa se také shodne na několika jasných hodnotách dobra, a stejně tak se shodne i na nutném boji proti zlu. Kde jinde si pak tyto shody ozřejmit než v dialogickém rozhovoru a setkání?

f) K předpokladům dialogu také patří vědomí, že samotný dialog má více vrstev a úrovní. V dialogu nejde jen o setkávání nejvyšších představitelů náboženství. Dialog je mnohem více každodenním setkáváním obyčejných věřících na ulici, ve škole, doma, v zaměstnání. ${ }^{7}$

Srov. Řehoř III. Laham. Moje milovaná Sýrie! Praha: Karmelitánské nakladatelství 2017, s. 53-78. 


\section{3. „Jak“ hlásat evangelium muslimům ${ }^{8}$}

V této části nám půjde o praktické náměty, „jak“ hlásat evangelium muslimům. Vycházíme z vlastní zkušenosti a znalosti islámu. Rozhodně nejde o výčet úplný, jelikož se opíráme o vlastní interpretaci charakteristik muslimské společnosti. Jde o první pokus, jak se s tématem vypořádat. Chceme tím podnítit další kolegy k promýšlení dané problematiky, případně ke korekci našich závěrů.

a) Je evidentní, že chceme-li hlásat evangelium jiné kultuře, musíme ji nejprve dobře poznat. $V$ našem případě by hlasatel Kristovy zvěsti měl být dobře informován a zpraven o islámu a o jednotlivých kulturách, odkud ten či onen posluchač pochází. Jistě postačí všeobecná znalost islámu, jeho hodnot, a také důvodů, které vedou muslimy k a priornímu odmítnutí křestanů. Pokud se počet muslimů v ČR zvýší - což se zatím nijak neděje -, měla by se domyslet kvalitní formace pastoračních pracovníků a katechetů ohledně základů islámu.

b) Protože islám není černým monolitem, ale širokou a pestrou škálou nejrůznějších proudů, tradic, ale i jednotlivých myslitelů, je pro hlasatele Krista nutné, aby se lidsky, tedy na přirozené rovině, seznámil s těmi muslimy, s nimiž žije ve svém městě. Odkud jsou, jakou mají historii, ke kterému proudu islámu se hlásí, jakým jazykem s nimi bude hovořit (tato otázka je naprosto klíčová), jaká je jejich zbožnost, kdo je jejich zdejší představitel?

c) Je také otázkou, kde bude docházet k hlásání Krista. V prvé řadě pravděpodobně půjde o neformální setkávání, později o možnost hovořit ke skupinám.

d) Logicky následným krokem je navázání kontaktu oficiální cestou, formou sdílení či spolupráce s místní muslimskou organizací na nejrůznějších rovinách (mezilidská, sociální, kulturní, vzdělávací). Tento krok zahrnuje zasílání zdravic k význačným muslimským svátkům, vzájemné přátelské navštěvování či pozvání muslimské komunity ke společné oslavě Vánoc jakožto oslavy narození Ježíše.

e) Muslimští věřící jsou obecně lidmi Muhammadových příběhů. V tzv. hadithech, tedy v tisícovkách zaznamenaných rčeních či

8 Srov. Maurice Borrmans. Islam e Cristianesimo. Le vie del dialogo. Cinisello Balsamo: Edizioni Paoline 1993; Giuseppe Scattolin. Islam e Dialogo. Bologna: EMI 2004; Michael L. Fitzgerald. Dialogo interreligioso. Il punto di vista cattolico. Cinisello Balsamo: Edizioni San Paolo 2007; Christian W. Troll. Distinguere per chiarire. Come orientarsi nel dialogo cristiano-islamico. Brescia: Queriniana 2009; Maurice Borrmans. Orientamenti per un dialogo tra cristiani e musulmani. Roma: Urbaniana University Press 2015. 
epizod z Muhammadova života, je zaznamenáno jeho vzorové chování a názory. ${ }^{9}$ Tyto př́běhy kolují po muslimském světě, mnozí věřící je znají nazpamět a vypravují si je a připomínají kdykoliv a kdekoliv. Proto navrhujeme, nejenom, aby se hlasatel s těmito příběhy seznámil, ale aby si z nich vybral i ty inspirující, které nějak odrážejí evangelijní pravdy. Zároveň nabádáme, aby se hlasatel Krista po tomto vzoru pevněji zakořenil $\mathrm{v}$ evangeliu a dokonale tak uměl životní okolnosti posluchačů komentovat a parafrázovat Ježíšovými př́iběhy. Čtyři evangelia nám poskytují dostatečný počet jeho příběhů či zázraků. A co více, muslimové Ježíše přijímají jako proroka, a proto k němu chovají respekt a úctu. V tomto bodu se tedy dotýkáme nejenom otázky „jak“, ale předkládáme zároveň i námět na obsah hlásání (viz kap. 4.).

f) Muslimové jsou lidmi orální a rétorické kultury. $O$ tom již svědčí Korán, který byl nejprve Muhammadem recitován, a muslimové věří, že teprve cca asi 20 let po jeho smrti se tento recitovaný text shromáždil a postupně zapsal. Dodnes existují definované kanonické recitace Koránu. Arabština je zrozena z Koránu a jím je dodnes měřena. Hlasatel Krista by tedy měl být výborný rétor, aby dokázal muslimy zaujmout. Tato dovednost obsahuje již zmíněnou otázku komunikačního jazyka, který by měl být zvolen. Pokud bude hlasatel Krista arabsky mluvícím, jistě by se měl dokonale seznámit se spisovnou arabštinou (tzv. Modern Standart Arabic), v níž povede kázání a hlásání, ale měl by se seznámit i s dialektem toho kterého národa, z něhož pocházejí jeho posluchači. At' užije jakéhokoliv jazyka, měl by hovořit plynně, záživně, živě, s gestikulací a jednoduchostí. Měla by to být silná a charismatická osobnost. Neměl by se bát poznat Korán a výše zmíněné hadithy natolik, aby se nějaké pasáže naučil nazpamět, a jimi pak argumentoval. Korán je z pohledu literárního text nesmírně široký a významově bohatý. I hlasatel Krista tam může ledacos dobrého objevit a zaujmout tím muslimského posluchače. ${ }^{10} \mathrm{Na}$ kvalitu hlasatele je tedy kladen poměrně velký nárok. ${ }^{11}$

g) Muslimové mají rádi striktní chování, zásadovost a pevné názory, přímočarost a černobílé vidění světa. Jsou také velmi spontánní a emocionálně citliví. Hlasatel Krista by na to měl být patřičně připraven. Vedle

9 Srov. Sunna. O chováni Proroka. Kniha výroků proroka Muhammada s komentárí. Praha: Islámská nadace v Praze 2006; Jahwá Al-Nawawí. Zahrady spravedlivých. Sbirka výroků proroka Muhammada. Praha: A.M.S. Trading 2008.

10 „A zjistíš, že lidé, kteří jsou největšími přáteli věřících, jsou ti, kdož říkají: Jsme křestané! A je to proto, že jsou mezi nimi kněží a mniši a že nejsou pýchou naplněni.“ K 5,82.

11 Inspirativní Humbert z Romans. Oformaci kazatelů. Praha: Krystal OP 2016, kap. X, s. $88-91$. 
zásadovosti, by se neměl vyhýbat patosu, který není muslimům cizí. Postačí také jednoduchost, jasnost a srozumitelnost. Velkým problémem je muslimské vidění kvalitativní odlišnosti mezi mužem a ženou. Vyvstává tedy otázka, nakolik se posluchačům přizpůsobit, a nakolik je formovat od počátku. Pokud bude platit první, pak by hlasatelem měl být spíše muž, v ženských komunitách však by jím měly být ženy.

h) V muslimských zemích má značnou důležitost rodinná mezigenerační sounáležitost. Často tak platí, že několik generací žije spolu pod jednou střechou. Důraz na rodinu a úctu ke svým předkům by měl být přínosem v mezináboženském dialogu a konkrétně přítomen v hlásání evangelia.

\section{Obsahové náměty pro hlásání evangelia}

Křestanské hlásání je radostným hlásáním Krista a jeho evangelia jako radostné zvěsti. ${ }^{12} \mathrm{~V}$ této části příspěvku se budeme snažit vystihnout ty evangelijní prvky a body, které by měly rezonovat u muslimských posluchačů. Chceme tedy čtenáři nabídnout úvahu, na jakých základech připravit kázání či promluvu. Zároveň musíme upozornit, že je na zvážení hlasatele, nakolik bude hovořit o evangeliu explicitně. Dle muslimské věrouky jsou totiž čtyři evangelia výsledkem zfalšování (tahrif) původně jednoho Ježíšova evangelia, které pravdivě odráželo část nebeského Koránu (K 3,3; 3,65; 5,46). Dle muslimů Ježíšovi posluchači a první věřící však tuto původní pravdu nepochopili a zapsali ji falešně. Proto nemají existující evangelia v očích muslimů valnou hodnotu. Lze ovšem hovořit o „evangeliu“ v singuláru - tím dojdeme u posluchačů k souznění s obsahem Koránu, kde se mnohokrát o evangeliu hovoří (K 3,3.48.65; 5,46-47.66-68.110; 7,157; 9,111; 48,29; 57,27).

a) Je vcelku obecně známo, že naše Písmo svaté (zvl. Starý zákon) má s Koránem společnou celou řadu postav (Abrahám, Mojžíšs, David, Jan Křtitel...) a epizod (zvěstování, ukřižování...). Ježíšovo jméno je př́tomno v Koránu (v 15 súrách a 93 verších), ${ }^{13}$ a často i v myšlenkách islámských učenců a literátů. ${ }^{14}$ Dějiny islámské teologie rovněž hovoří

12 Srov. Pavel VI. Evangelii nuntiandi (apoštolská exhortace Pavla VI. z 8. prosince 1975). Praha: Zvon 1990; František. Evangelii gaudium.

13 Srov. Maurice Borrmans. Islam e Cristianesimo. Le vie del dialogo. Cinisello Balsamo: Edizioni Paoline 1993, s. 57.

14 Srov. Giulio Basetti Sani. Gesù Cristo nascosto nel Corano. Verona: Il Segno 1994; Maurice Borrmans. Jésus et les musulmans d'aujourd'hui. Paris: Desclée 1996; Tarif 
o tajemství člověka a o jeho roli ve stvoření, řeší podobné otázky jako v křestanských dějinách (predestinace a svobodná lidská vůle, stvořenost či nestvořenost slova Božího, ospravedlnění skrze víru, povaha atributů Božích...). Všechna tato společná témata jsou pobídkou k rozhovoru. Hlásání Krista a jeho evangelia lze postavit na těchto styčných bodech z Koránu či na úvahách z historie islámského myšlení. ${ }^{15}$

b) Poznáme-li výklad islámské víry, neměli bychom být překvapeni, kolik toho rezonuje s naším krédem: víra v jediného Boha stvořitele; věčné slovo Boží, které se zjevuje lidstvu (pro křestany je to Ježíš, pro muslimy Korán); víra ve zjevujícího se Boha, který hovoří a i přes svou transcendenci ve světě působí; spásonosné Ježíšovo utrpení, které může být podobné šíitskému vnímání záchrany v utrpení Husajna a jeho rodiny při masakru v Karbale v r. 680 (tzv. ašúra) $;^{16}$ Duch svatý, jenž mluvil ústy proroků (z nichž mnohé přijímá i islámská tradice, která rozsáhle domýšlí instituci proroka); i přesto, že o „duchu božím“ Korán hovoří, nejde v muslimské interpretaci o božskou osobu (např. K 2,87.253; 4,171; 5,110; 12,87; 16,102 atd.); víra v církev jako společenství svatých a štastných zemřelých pak rezonuje s muslimským pojetím obce věřících (umma).

c) Je jasné, že vlastním předmětem hlásání a dialogu by měla být postava Ježíše Krista. To, co nás s muslimy spojuje, je jeho lidství, jeho prorocké poslání, případně poslání naplnit starozákonní mesiášské př́sliby. Muslimové Ježíše totiž chápou jako předposledního proroka, který přislíbil ještě jednoho, tentokrát toho definitivního, kterým je Muhammad. Tak sami interpretují Ježíšův příslib příchodu Parakléta z Janova evangelia (kap. 14-17). Proto se nabízí v hlásání i dialogu hojně využívat Matoušovo evangelium, které je silně poznamenáno polemikou s judaismem a židokřestanským myšlením, či argumentaci z Pavlových listů (Řím, Gal), i přesto, že muslimové sv. Pavla nemají př́liš v lásce.

Khalidi. The Muslim Jesus. Sayings and stories in islamic literature. Cambridge Mass: Harvard University Press 2001; Giuseppe Rizzardi. 'İsā ibn Maryam. Lo sguardo dell'Islām su Gesù. Milano: Centro Ambrosiano 2007; Sabino Chialà (ed.). I Detti Islamici di Gesù (překl. Ignazio de Francesco). Milano: Mondadori 2009.

15 „Pane náš, neměj nám za zlé, jestliže jsme zapomněli či chybili! Pane náš, nenakládej na nás břímě tíživé, podobné tomu, jež jsi naložil na ty, kdož byli před námi! Pane náš, nenakládej nám břemena, která nemůžeme unést, a vymaž nám chyby naše, smiluj se nad námi a odpust' nám! Tys ochráncem naším, pomoz nám k vítězství nad lidem nevěřícím!“ K 2,286.

16 Srov. Libor Čech. Írán a kultura mučednictví. Od zbožnosti k protestu. Praha: Academia 2016. 
d) Pokud je v Koránu př́tomno, že Bůh má slovo (kalima; K 3,45) i svého ducha (rúh; K 15,29), proč tak rezolutně nepřijímají Trojici? Pokusme se krátce odpovědět a vyvodit praktické závěry. Bůh muslimů je striktně jeden, jediný a nanejvýše jednoduchý, který „neplodil, ani není zplozen“, jak říká 112. súra Koránu. Nelze na něj aplikovat žádné „lidmi vymyšlené kategorie“, např. z filosofie (např. osoba, esence, podstata, vlastnosti atd.), kromě jím samotným zvolených „překrásných jmen Božích,“ zmíněných přímo v Koránu. Čistota jedinosti je pro muslimy „posvátná“, ${ }^{17}$ oni tedy nechtějí a - do jisté míry z důvodu svého svědomí - ani nemohou přijmout představu o tom, že by byl Bủh ve třech osobách jediný. Uznáním Ježíše jako Božího Syna by se narušila čistá, posvátná jedinost Boží (tawhíd). Snad sem patří myšlenka, že bychom mohli nad islámem přemýšlet a vidět ho jako určitý svérázný typ „starozákonního monoteismu“ (inspirativní četba v knihách Jozue či Amos). Pak by i islám mohl být jednoduše chápán v jeho adventním očekávání příchodu Soudného dne a Boží vlády. S tím pak souvisí i náš možný teologický pohled na islám. Alláh muslimů může být interpretován jako nedokonale poznávaný Bůh Otec, analogicky jako Hospodin našich starších bratrů ve víře, židů. ${ }^{18}$

d) Dalším podnětným oborem, z něhož lze vycházet na základě společných prvků, je eschatologie. Eschatologické prvky patří vůbec k těm nejstarším vrstvám $\mathrm{v}$ Koránu. Jsou to mnohdy dosti reálně popisované důsledky etického chování a běžné praxe. V současnosti místy nabývá na aktuálnosti islámská apokalyptika. ${ }^{19}$ Pokud si poslechneme páteční promluvy imámů v muslimských zemích, pak často uslyšíme živé popisy pekla a vyvolání strachu z něj. Proto hlásat evangelium na základě společného putování k nebeskému městu Božímu se jeví jako více než inspirativní, zvláště pokud své hlásání postavíme pozitivně na nebi a na naději, a nikoliv negativně na pekle a na strachu.

Srov. Giuseppe Scattolin. Bůh v islámu. Salve. Revue pro teologii a duchovni život 27 (2017), č. 2-3, s. 39-55.

18 Srov. Ctirad V. Pospíšil. Jako v nebi, tak i na zemi. Nácrrt trinitární teologie. 3. vydání. Kostelní Vydří: KNA / Praha: Krystal OP 2017, s. 33-35.

19 Srov. Jean-Pierre Filiu. Apokalypsa v islámu. Praha: Volvox Globator 2011; Helmut Werner (ed.). Islámská kniha mrtvých. Představy islámu o onom svété. Podle drážd'anského a lipského rukopisu. Praha: Pragma 2002; Bronislav Ostřanský. Na konci dějin: Islámský stát a apokalyptická rétorika. In: Ondřej Beránek - Bronislav Ostřanský (eds.). Islámský stát: Blízký východ na konci časủ. Praha: Academia 2016, s. 101-137. 
e) Poskytující základ našemu hlásání jsou také společné prvky ve zbožnosti. Mělo by jít o vysvětlování souvislostí a odlišností. Tak například: růženec jako modlitba spjatá s příběhy Ježíšova pozemského života, oproti opakování 99 krásných jmen Božích v tzv. subha, příp. dzikru; poslech Božího slova, přijímání a adorace eucharistického Těla a Krve Páně, oproti adoraci slova Božího poslechem slavné recitace Koránu; vykonávání náboženských poutí na významná místa spojená s křestanskou vírou, oproti povinné pouti do Mekky, kterou

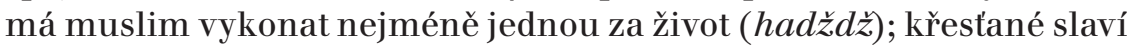
mši svatou mj. jako následování Ježíšových slov a gest při poslední večeři a jako památku Kristovy velikonoční oběti, oproti tomu muslimové při povinné pouti do Mekky napodobují poslední pout Muhammada; křestanské skutky duchovního a tělesného milosrdenství, oproti často $\mathrm{v}$ raných vrstvách Koránu proklamovaným činům milosrdenství k chudým, nuzným, ubohým, sirotkům, vdovám, nejjasněji pak almužně pro chudé (zakát), která patří ke čtyřem povinnostem islámské víry (vedle almužny: vyznání víry, pout do Mekky, povinná liturgická modlitba, půst v měsíci Ramadán). ${ }^{20}$ Podobných projevů zbožnosti je celá řada a nesou v sobě potenci být základem dialogu i hlásání radostné zvěsti.

f) Neměli bychom bez povšimnutí přejít bohatství arabské klasické literatury. Některá význačná díla jsou do češtiny přeložená (např. příběhy Tisice a jedné noci, a Kalíla a Dimna, alias Bidpájovy bajky ${ }^{21}$ a mohou nám poskytnout poměrně dobrý a kvalitní vhled do arabské kultury. Trpělivé poznávání těchto děl a některých příběhů z nich by mohlo vést k poměrně fascinujícímu objevováním skrytých prvků dobra, pravdy, lásky a moudrosti, které samy vedou ke Kristu, vždyt' samy pochází z Ducha svatého (např. Lumen gentium, čl. 4; Tomáš Akvinský. Summa Theologica, I-II, q. 109, art. 1, ad 1). ${ }^{22}$

20 Srov. Lukáš Nosek. Deskripce islámské víry. Věnováno památce prof. Rudolfa Macúcha. Verbum. Časopis pre krestanskú kultúru 28 (2017), č. 2, s. 13-40.

21 Srov. Tisic a jedna noc. Sv. I-V (přel. Felix Tauer). Praha: Odeon 1973-1975; Kalíla a Dimna. Bidpájovy bajky (z arabského originálu přeložil, doslov a poznámky napsal Jaroslav Oliverius). Brandýs n. L.: Gema Art Group - Dar Ibn Rushd 2005.

22 „Všichni jsou v tom žaláři, jejž stvořili si sami sobě / at stálice Východu, at oběžnice franckých zemí. / At to jsou pírové církve, šejchové posvátné káby / novost řeči ani novost činu v nižádném z nich není. / Lidé politiky jsou jen samé vytáčky a kličky / básník též je v chudobinci obrazotvornosti zkříslý. / Svět už dávno potřebuje takového spasitele / jenž způsobí zemětřesení ve světě lidské mysli.“ Muhammad Ikbál, Pravý spasitel (báseň). In: Muhammad Ikbál. Hlas karavanního zvonku (přel. Václav Daněk a Jan Marek). Praha: Odeon 1977, s. 123. 
g) S předcházejícím bodem souvisí ještě jeden: naplňovat klíčové muslimské pojmy novým (křestanským) obsahem. Například termín šaría je sice vnímán jako synonymum pro dodnes platný středověký zákoník islámu, po letmém studiu však zjistíme, že původní význam arabského termínu šaría je cesta k prameni vody. ${ }^{23}$ Prameny, studny byly více než důležité ve vyprahlé pouštní arabské krajině. Kdo tuto cestu znal, přežil. Později se tato myšlenka ujala jako pojmenování pro v Koránu a v tradici uložené normy a principy, které jsou pro věřícího povinnou cestou k životu, k poznání, a konečně pravým zákonem Božím. Nahlížíme-li tento výklad pohledem křestana, nemůžeme v něm vidět odlesk dávné lidské touhy a žízně po živé vodě, kterou může uspokojit pouze Ježíš Kristus jako pravý nositel živé vody?24 Nemůžeme tedy trpělivě vysvětlovat muslimům, že pro ně může být pravou, novou šaríou Ježíš, který jim jediný dá pravdu a svobodu Božích dětí? Vždyt' jedině on dává vše jisté a sám je více než šari'a.

Dalším inspirativním termínem je tawhíd, tedy striktní jedinost Boží. Sami muslimští autoři hovoří o jeho obrovském vnitřním bohatství, které neobsáhne několik pojmů. Užít nějaký pojem hraničí s idolatrií tohoto pojmu. Proto tuto významovou mnohost věřeného tajemství redukují jen na termín tawhíd. Boží jedinost a jednoduchost tedy překypuje mnohostí a vyjadřuje se v rozmanitosti života i celého vesmíru. Muslimové tuší, že tawhid v sobě „tajemně - nepochopitelně“ obsahuje mnohost. Z těchto důvodů pak plyne naše otázka: Není termín tawhíd spíše odkazem na apofatickou teologii než katafatickým konstatováním? ${ }^{25}$ Potažmo není tawhid ve své hloubce právě tím odkazem na trojiční život Boží? Není proto potřeba hovořit o Bohu jako o zdroji života a rozmanitosti?

Dalším muslimským termínem je Korán, který je „zjevené, seslané a prrítomné" slovo Boží. Ježíš Kristus je pak vtělené Slovo, člověk k lidem poslaný, který nejen mluví slova Boží, ale on sám je tím Slovem, on sám dovršuje dílo spásy, které mu Otec uložil vykonat. Kdo vidí Ježíše, vidí Otce (srov. Dei verbum, čl. 4). Neměli bychom hlouběji promýšlet vztah Koránu a Ježíše? Není Ježíš tím novým Koránem - protože není

\footnotetext{
23 Srov. Jan Potměšil. Šarīa. Úvod do islámského práva. Praha: Grada 2012, s. 18-19.

24 Srov. Papežský rada pro kulturu - Papežská rada pro mezináboženský dialog. Ježíš Kristus, nositel živé vody. Křestanské zamyšlení nad „New Age“. Praha: Česká biskupská konference 2003.

25 Srov. Giuseppe Scattolin. Bůh v islámu. Salve. Revue pro teologii a duchovní život 27 (2017), č. 2-3, s. 39-55.
} 
jen slovem, ale i božsko-lidskou osobou - ve kterém se člověk vždy a všude setkává s Bohem Otcem?26

Dalším termínem je 'ášúrá šíitského islámu. Tedy připomínání bolestné a konstitutivní historie daného proudu islámu. Tento svátek je vnímán skoro jako zástupná a téměř vykupitelská bolest a smrt Husajna v bitvě u Karbalá roku 680. Neměli bychom s šíity mluvit o Ježíši prizmatem jejich chápání Husajnovi smrti? Tedy že podobně i Ježíš na sebe bere bolest a smrt?

Pravé umění naplňovat klíčové muslimské pojmy novým obsahem bude spočívat $\mathrm{v}$ prvé řadě $\mathrm{v}$ tom, že již v našich životech uvidí stopy Ježíšova příkladu, který jim rozhodně není neznámý.

\section{Závěr}

V závěru ještě jednou připomeneme, že tento článek je úvodním přemítáním nad otázkou, jakým způsobem hlásat evangelium muslimům žijících v ČR. Výčet námětů rozhodně není úplný. Problematika je značně široká a otevřená k dalšímu promýšlení.

Domnívám se, že vzrůstající počet muslimů na starém kontinentě by pro křestany neměl být důvodem k obavám, ${ }^{27}$ strachu či k pouze ideovému ahistorickému návratu do jakési zlaté historické epochy „kdy bylo lépe“, a tedy důvodem ke stavění zdí vůči cizímu. Není spíše současný stav příležitostí, kterou nám připravil Bůh trojjediný? ${ }^{28}$ Patrně je to výzva, abychom se vzájemně poznávali, hovořili spolu, překonávali zažité předsudky a stereotypy, abychom vzájemně spolupracovali a nazírali svět čím dál více Božím pohledem. ${ }^{29}$ Možná právě tímto způsobem máme poznávat jeho vůli, která se tajemně zjevuje ve „znameních času“. ${ }^{30}$ Vždyt Bůh chce, aby všichni lidé došli spásy (srov. 1 Tim 2,4). Jak říká sv. Tomáš Akvinský, pravda může přijít od kohokoliv,

26 Srov. Lukáš Nosek. Hermeneutický klíč pro křestanský pohled na islám. Salve. Revue pro teologii a duchovní život 27 (2017), č. 2-3, s. 9-24.

27 Že je fenomén „strach z islámu a migrace“ součástí dezinformační atmosféry v naší zemi, a tedy velmi ceněným předvolebním artiklem, dokládá např. Alexandra Alvarová. Průmysl lži. Propaganda, konspirace a dezinformační válka. Praha: Triton 2017.

28 Srov. Pavel Hošek. Islám jako výzva pro křestany. Co máme tedy dèlat tvář́ v tvár tomu, co vidime kolem sebe?. Praha: Návrat domů 2016.

29 Srov. Luigi Basanese. The Question of "True Islam": Europe faces Salafism. In: Jaroslav Franc (ed.). Europe and Islam. Olomouc: Refugium 2015, s. 19-48.

30 Srov. Christian W. Troll. Distinguere per chiarire. Come orientarsi nel dialogo cristiano-islamico. Brescia: Queriniana 2009, s. 13. 
vždy je výlučně od Ducha svatého: „Omne verum a quocumque dicatur a Spiritu sancto est."51

Pokusili jsme se předložit náčrt problematiky dialogu a hlásání Ježíše Krista muslimům v České republice. Jak jsme několikrát uvedli, rozhodně jej nepokládáme za dokonalý, definitivní či kompletní. Jde pouze o několik inspirací, které jsme se pokusili formulovat a předat českému čtenáři. Naše úvahy chceme uzavřít ještě jinou korekcí. Stále totiž trvá mnohem vznešenější návod, jak být dobrým kazatelem a hlasatelem, který pravděpodobně mnohem jasněji platí v případě, kdy posluchači budou muslimové. Formulujeme jej slovy pátého magistra Řádu bratři kazatelů Humberta z Romans. „Má-li tedy být kázání záslužné pro kazatele samého, stejně jako prospívat těm, kdo mu naslouchají, nesmí kazatel kázat bez pověření, nesmí být nechvalně známý hříšník, nesmí se odchýlit od pravdy, jeho jednání musí být v souladu s tím, co říká, musí jej víc zajímat duchovní př́nos než pozemský zisk, musí vyhledávat to, co náleží Bohu, spíš než to, co náleží jemu samému, nesmí kázat tak, aby druhé pomlouval, nesmí znepokojovat své posluchače pošetilými slovy, nesmí dát prŕležitost jakémukoliv zlu, nesmí být zřejmé, že nekoná pokání, a v jeho úmyslu nesmí chybět láska.“32 Snad můžeme ještě parafrázovat, že pravým hlasatelem a kazatelem Krista je člověk spíše způsobem života a svou připraveností svědčit o zmrtvýchvstalém Kristu než charismatem lidské výmluvnosti. ${ }^{33}$

Katedra fundamentální a dogmatické teologie Katolická teologická fakulta Univerzity Karlovy

Thákurova 3

160 Praha 6

E-mail:nosek@ktf.cuni.cz

31 Srov. Tomáš Akvinský. Summa Theologica, I-II, q. 109, art. 1, ad 1.

32 Srov. Humbert z Romans. O formaci kazatelù. Praha: Krystal OP 2016, kap. XI, s. 91-92.

33 Benedikt T. Mohelník. Předmluva k českému vydání. In: Humbert $z$ Romans. O formaci kazatelů. Praha: Krystal OP 2016, s. 5. 